\title{
The combined effect of chemical composition and cooling rate on transformation temperatures of hypoeutectoid steels
}

\author{
I. Schindler*, J. Němec, P. Kawulok, R. Kawulok, V. Ševčák, P. Opěla, S. Rusz \\ $V \breve{B}$ - Technical University of Ostrava, Faculty of Metallurgy and Materials Engineering, \\ 17. listopadu 15, 70833 Ostrava, Czech Republic
}

Received 12 March 2018, received in revised form 28 April 2018, accepted 10 May 2018

\begin{abstract}
The transformation temperatures $A_{\mathrm{r} 3}$ and $A_{\mathrm{r} 1}$ of four unalloyed hypoeutectoid steels with a carbon content of $0.029-0.73 \%$ were determined using dilatometric tests. Unusually high cooling rates of 2 and $8^{\circ} \mathrm{Cs}^{-1}$ were used intentionally, corresponding to the conditions in the wire rod rolling mills. The developed regression models are phenomenological and allow a simple prediction of transformation temperatures, depending only on the cooling rate and the chemical composition of the steel represented by the carbon equivalent (in the case of $A_{\mathrm{r} 1}$ ), respectively by the $A_{\mathrm{c} 3}$ temperature (for $A_{\mathrm{r} 3}$ ). When calculating the $A_{\mathrm{c} 3}$ temperature, it was worth considering its non-linear dependence on carbon content. It has been verified that the derived equations are applicable even at relatively low cooling rates when the austenite decomposes exclusively on ferrite and pearlite.
\end{abstract}

K e y w o r d s: hypoeutectoid steel, carbon equivalent, dilatometer test, cooling rate, decomposition of austenite, transformation temperature

\section{Introduction}

The mechanical properties of the steel rolled products can be effectively influenced by the course of the structure-forming processes accompanying the hot forming (especially the static recrystallization) and cooling from the finish rolling temperature (especially the phase transformations). The phase composition of the material and the final grain size are decisive for its plastic and strength properties - see the well-known Hall-Petch relationship and its connection with grain boundary strengthening, e.g. [1-3]. Under real operating conditions, it is difficult to control and significantly change the forming process history in the case of continuous mills for the long products rolling (shaped rods, wire, etc.). The technology is limited to, amongst other things, the requirements for the rolling groove design, speeds and time intervals during continuous rolling and controlled cooling. The most feasible thing to do is to control the two basic parameters - the temperature and the intensity of the finished product cooling. In the case of steels in the austenitic region, it is advisable to finish rolling at a tempera- ture just above $A_{\mathrm{r} 3}$, since the last deformation at too high temperature can lead to the undesirable growth of the recrystallized grains even before the austenite decomposition begins. Therefore, it is important to provide the most accurate prediction of the $A_{\mathrm{r} 3}$ temperature, which, apart from the chemical composition of the steel, is also influenced by the cooling rate, previous deformation and austenitic grain size $[4,5]$. All additive elements in steel, except silicon, cobalt, and aluminum, increase the stability of austenite and reduce the transformation temperatures $A_{\mathrm{r} 3}$ and $A_{\mathrm{r} 1}$ $\left({ }^{\circ} \mathrm{C}\right)$. The kinetics of ferritic transformation is significantly affected by manganese and carbon. They slow down diffusion, lower the $A_{\mathrm{r} 3}$ temperature, and shift the entire ferrite area in the CCT diagrams to the right [6]. The decomposition of deformed austenite on ferrite or pearlite occurs at higher temperatures than phase transformation without previous deformation, which is confirmed by many works - see e.g. [7, 8]. The acceleration effect of deformation is manifested especially at the beginning of these transformations. Deformation increases the number of lattice defects, which promotes the diffusion of all atoms in the solid solu-

\footnotetext{
*Corresponding author: e-mail address: $\underline{\text { ivo.schindler@vsb.cz }}$
} 
Table 1. The chemical composition of tested steels (alloy content of individual elements in wt.\%)

\begin{tabular}{ccccccccccccc}
\hline Steel & $\mathrm{C}$ & $\mathrm{Mn}$ & $\mathrm{Si}$ & $\mathrm{P}$ & $\mathrm{S}$ & $\mathrm{Cu}$ & $\mathrm{Cr}$ & $\mathrm{Ni}$ & $\mathrm{Al}$ & $\mathrm{Mo}$ & $\mathrm{V}$ \\
\hline $\mathrm{U}$ & 0.029 & 0.27 & 0.03 & 0.011 & 0.015 & 0.05 & 0.06 & 0.03 & 0.004 & 0.008 & 0.003 \\
$\mathrm{~L}$ & 0.084 & 0.38 & 0.06 & 0.011 & 0.007 & 0.03 & 0.04 & 0.02 & 0.030 & 0.008 & 0.004 \\
$\mathrm{M}$ & 0.42 & 0.66 & 0.22 & 0.010 & 0.014 & 0.04 & 0.06 & 0.03 & 0.002 & 0.009 & 0.002 \\
$\mathrm{H}$ & 0.73 & 0.57 & 0.20 & 0.011 & 0.011 & 0.05 & 0.05 & 0.02 & 0.002 & 0.008 & 0.002 \\
\hline
\end{tabular}

Table 2. Calculation results for different chemical compositions

\begin{tabular}{clccc}
\hline Steel & $\mathrm{C}(\%)$ & $C E(\%)$ & $A_{\mathrm{c} 1}\left({ }^{\circ} \mathrm{C}\right)$ & $A_{\mathrm{c} 3}\left({ }^{\circ} \mathrm{C}\right)$ \\
\hline $\mathrm{U}$ & 0.029 & 0.09 & 736 & 894 \\
$\mathrm{~L}$ & 0.084 & 0.16 & 735 & 867 \\
$\mathrm{M}$ & 0.42 & 0.55 & 728 & 787 \\
$\mathrm{H}$ & 0.73 & 0.84 & 721 & 742 \\
\hline
\end{tabular}

tion and leads to faster nucleation and grain growth of the new phase $[9,10]$. Phase transformations based on the diffusion mechanism use nucleation and subsequent growth of new grains especially on the original grain boundaries. A finer austenitic grain brings more nucleation sites, causing an increase in $A_{\mathrm{r} 3}$ temperature and acceleration of ferritic transformation [11, 12]. Very different cooling rates can affect not only kinetics but also the kind of phase transformations. With faster cooling, the formation of quenched components is more presumable.

The work aimed to describe the influence of chemical composition and, to a limited extent, of cooling rate on temperatures $A_{\mathrm{r} 3}$ and $A_{\mathrm{r} 1}$ of unalloyed hypoeutectoid steels. The phenomenological approach was chosen intentionally for a simple description of experimental data without complicated mathematical models characterized by a strong physical basis. The resulting equations should allow a fast and sufficiently accurate prediction of $A_{\mathrm{r} 3}$ and $A_{\mathrm{r} 1}$ temperatures only by knowledge of the chemical composition of unalloyed hypoeutectoid steels and by considering the effect of the constant cooling rate $\mathrm{CR}\left({ }^{\circ} \mathrm{C} \mathrm{s}^{-1}\right)$. In contrast to other, much more complex approaches, high CR values were chosen in a relatively narrow range from 2 to $8^{\circ} \mathrm{Cs} \mathrm{s}^{-1}$, which corresponds, for example, with the common conditions of controlled cooling of the rolled wire loops on a Stelmor conveyor system. In the case of the investigated steels, this limited approach guarantees a decomposing of austenite to ferrite and pearlite in different proportions, and research should not be complicated by other types of phase transformations (bainitic or martensitic) at high cooling rates.

\section{Materials and experimental methods}

Transformation temperatures were determined based on dilatometry tests for a total of four unalloyed steels: two low-carbon (with 0.029 and/or $0.084 \% \mathrm{C}$ ), one medium-carbon (with $0.42 \% \mathrm{C}$ ) and one high-carbon (with $0.73 \% \mathrm{C}$ ). Their designation and chemical composition are given in Table 1 .

Table 2 lists the carbon equivalent values $C E(\%)$ and transformation temperatures, calculated based on the chemical composition of the individual steels. The formula adopted by the International Institute of Welding was used for $C E$ calculation (which is a somewhat simplified form of Dearden and O'Neill's [13] formula for hardenability):

$C E=\mathrm{C}+\mathrm{Mn} / 6+(\mathrm{Cr}+\mathrm{Mo}+\mathrm{V}) / 5+(\mathrm{Cu}+\mathrm{Ni}) / 15 .(1)$

Temperatures $A_{\mathrm{c} 1}\left({ }^{\circ} \mathrm{C}\right)$ and $A_{\mathrm{c} 3}\left({ }^{\circ} \mathrm{C}\right)$ were calculated with approved equations of Trzaska and Dobrzański [14]:

$$
\begin{gathered}
A_{\mathrm{c} 1}=739-22.8 \mathrm{C}-6.8 \mathrm{Mn}+18.2 \mathrm{Si}+ \\
-11.7 \mathrm{Cr}-15 \mathrm{Ni}-6.4 \mathrm{Mo}-5 \mathrm{~V}-28 \mathrm{Cu} \\
A_{\mathrm{c} 3}=937.3-224.5 \sqrt{\mathrm{C}}-17 \mathrm{Mn}+34 \mathrm{Si}- \\
-14 \mathrm{Ni}+21.6 \mathrm{Mo}+41.8 \mathrm{~V}-20 \mathrm{Cu} .
\end{gathered}
$$

Alloy content of individual elements in Eqs. (1)-(3) as well as in all following relationships is in wt.\%.

The transformation temperatures were determined from the dilatometric curves obtained using the dilatometer module mounted on the DSI HDS-20 hot deformation simulator. Model 39112 scanning noncontact optical dilatometer system uses high-intensity GaN-based light-emitting diodes combined with an HL-CCD sensor to provide high-speed measurement with no moving parts. This system has twice the speed of conventional laser-based measurement units, with a scan rate of 2400 scans per second and a resolution of $\pm 0.3 \mu \mathrm{m}$. Information from the sample measurement is displayed in real time on the LCD unit and sent to the computer for data acquisition [15]. 
Table 3. Experimentally determined transformation temperatures

\begin{tabular}{ccccc}
\hline Steel & $\mathrm{C}(\%)$ & $\mathrm{CR}\left({ }^{\circ} \mathrm{C} \mathrm{s}^{-1}\right)$ & $A_{\mathrm{r} 1}\left({ }^{\circ} \mathrm{C}\right)$ & $A_{\mathrm{r} 3}\left({ }^{\circ} \mathrm{C}\right)$ \\
\hline $\mathrm{U}$ & 0.029 & 2 & 761 & 879 \\
$\mathrm{U}$ & 0.029 & 8 & 755 & 872 \\
$\mathrm{~L}$ & 0.084 & 2 & 723 & 859 \\
$\mathrm{~L}$ & 0.084 & 8 & 713 & 843 \\
$\mathrm{M}$ & 0.42 & 2 & 624 & 728 \\
$\mathrm{M}$ & 0.42 & 8 & 608 & 711 \\
$\mathrm{H}$ & 0.73 & 2 & 621 & 684 \\
$\mathrm{H}$ & 0.73 & 8 & 597 & 669 \\
\hline
\end{tabular}

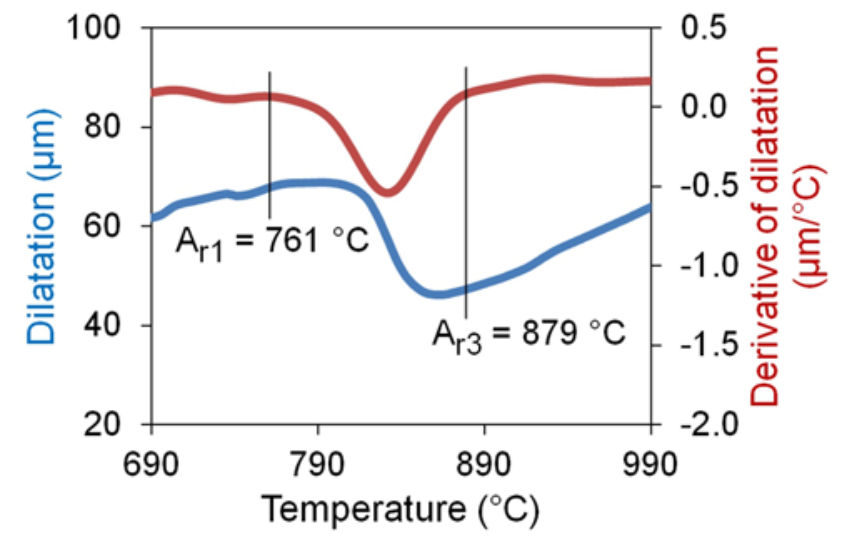

Fig. 1. Dilatation of the U steel in the course of cooling at a rate of $2^{\circ} \mathrm{C} \mathrm{s}^{-1}$.

From hot-rolled wire rods of $10 \mathrm{~mm}$ diameter, cylindrical samples with a diameter of $6 \mathrm{~mm}$ and length of $86 \mathrm{~mm}$ were made. Measured and computerized variations in sample diameter (i.e., dilatation in $\mu \mathrm{m}$ ) were recorded as a function of the temperature changes provided in the center sections of the samples by the resistance heating. Determination of austenitizing temperatures was inspired by the approach of Vanderschueren et al. [16]. Austenitization temperatures of $A_{\mathrm{c} 3}+60^{\circ} \mathrm{C}$ were chosen, where the $A_{\mathrm{c} 3}$ temperatures calculated for each steel are shown in Table 2 .

\section{Evaluation and mathematical description of experimental data}

In Figs. 1-4 there are shown important parts of selected dilatometric curves and their derivatives in $\mu \mathrm{m}^{\circ} \mathrm{C}^{-1}$, calculated using the Origin software. The temperatures $A_{\mathrm{r} 3}$ and $A_{\mathrm{r} 1}$ were determined from changes in temperature dependences of dilatation, respectively its derivatives (see e.g. $[17,18]$ ) and summarized in Table 3.

From a mathematical point of view, description of the transformation temperature $A_{\mathrm{r} 3}$ was shown to be simpler. It has been discovered that the calculated $A_{\mathrm{c} 3}$

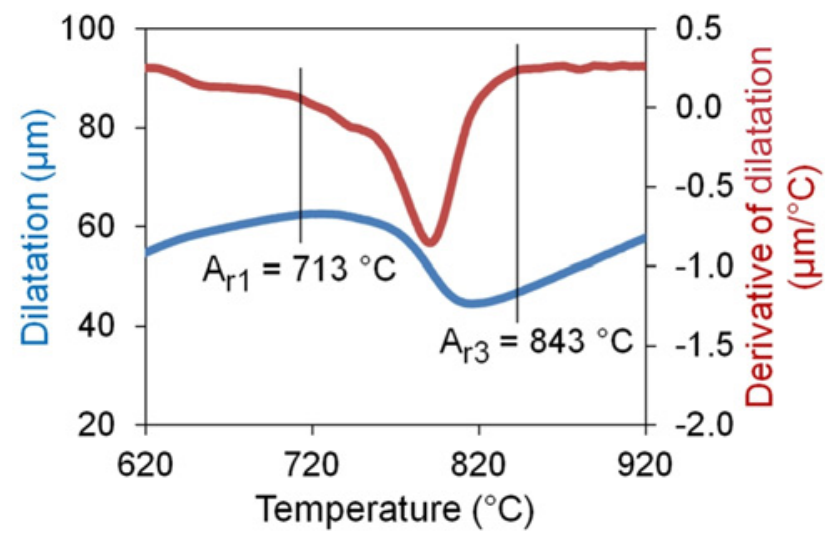

Fig. 2. Dilatation of the L steel in the course of cooling at a rate of $8^{\circ} \mathrm{C} \mathrm{s}^{-1}$.

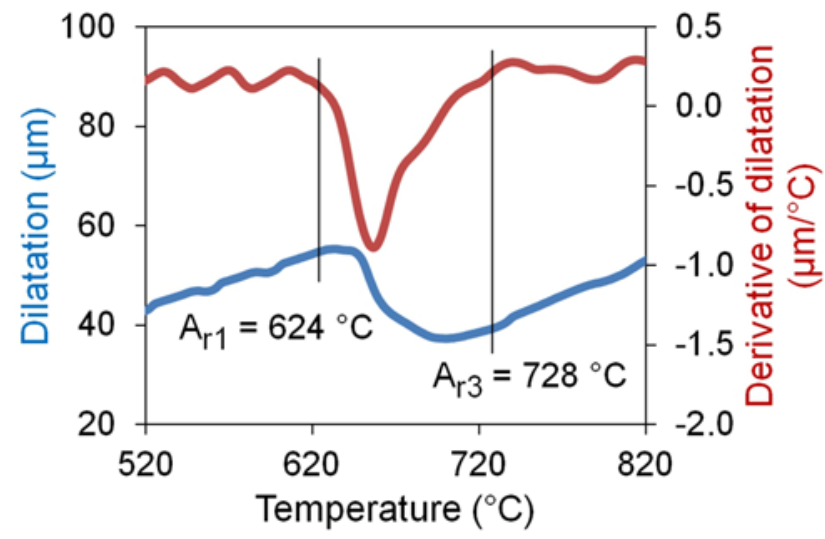

Fig. 3. Dilatation of the $\mathrm{M}$ steel in the course of cooling at a rate of $2{ }^{\circ} \mathrm{C} \mathrm{s}^{-1}$.

values and $A_{\mathrm{r} 3}$ temperatures measured for both cooling rates have a close connection. This is evident from Fig. 5, plotting the given trends according to the carbon equivalent. The secondary finding was that, according to Eq. (3), the calculated $A_{\mathrm{c} 3}$ temperatures very accurately depended on the magnitude of $C E$, which could be described by the regression polynomial of the $2^{\text {nd }}$ degree. 


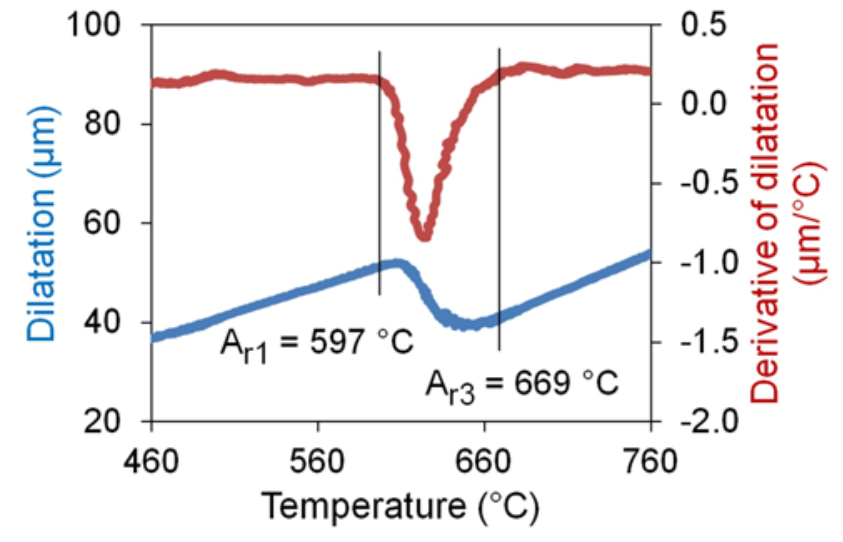

Fig. 4. Dilatation of the $\mathrm{H}$ steel in the course of cooling at a rate of $8^{\circ} \mathrm{C} \mathrm{s}^{-1}$.

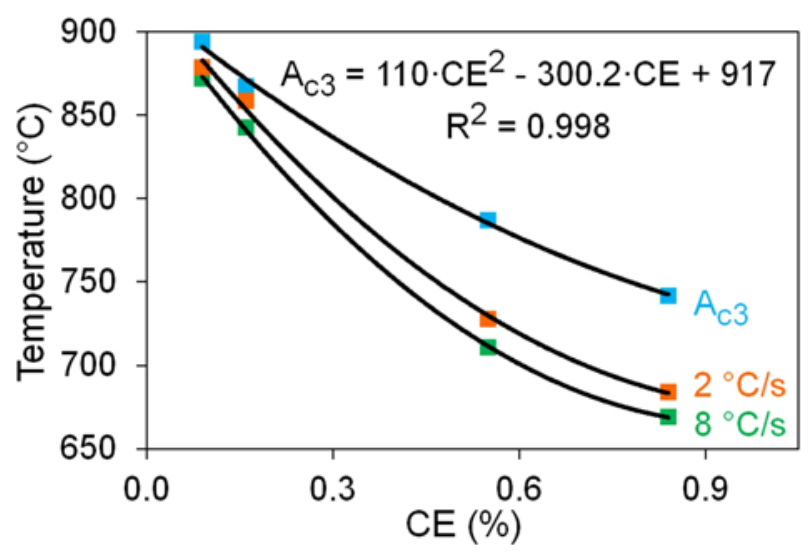

Fig. 5. Temperatures $A_{\mathrm{c} 3}$ and $A_{\mathrm{r} 3}$ (for cooling rates of 2 and $\left.8{ }^{\circ} \mathrm{C} \mathrm{s}^{-1}\right)$ in dependence on $C E$ values.

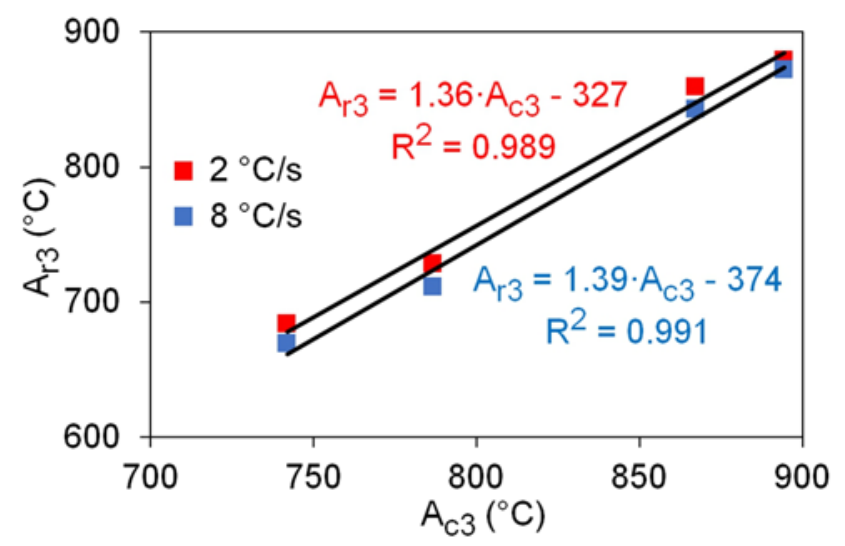

Fig. 6. Measured values of $A_{\mathrm{r} 3}$ (for cooling rates of 2 and $\left.8^{\circ} \mathrm{C} \mathrm{s}^{-1}\right)$ in dependence on calculated temperatures $A_{\mathrm{c} 3}$.

The next step was to find the relation between the experimental values of $A_{\mathrm{r} 3}$ and the calculated $A_{\mathrm{c} 3}$ temperatures. As can be seen from Fig. 6, the linear

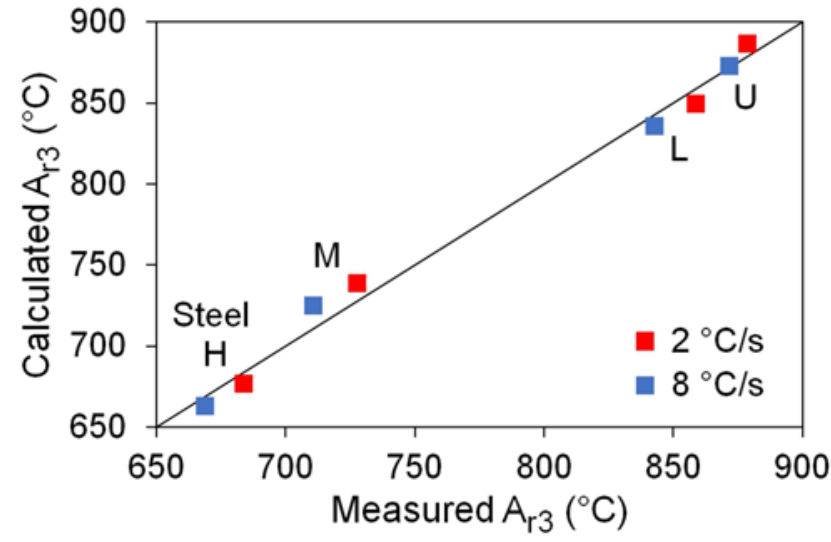

Fig. 7. The relation between measured and calculated $A_{\mathrm{r} 3}$ temperatures (according to Eq. (4)) (distinguishing the values obtained at cooling rates of 2 and $\left.8^{\circ} \mathrm{C} \mathrm{s}^{-1}\right)$.

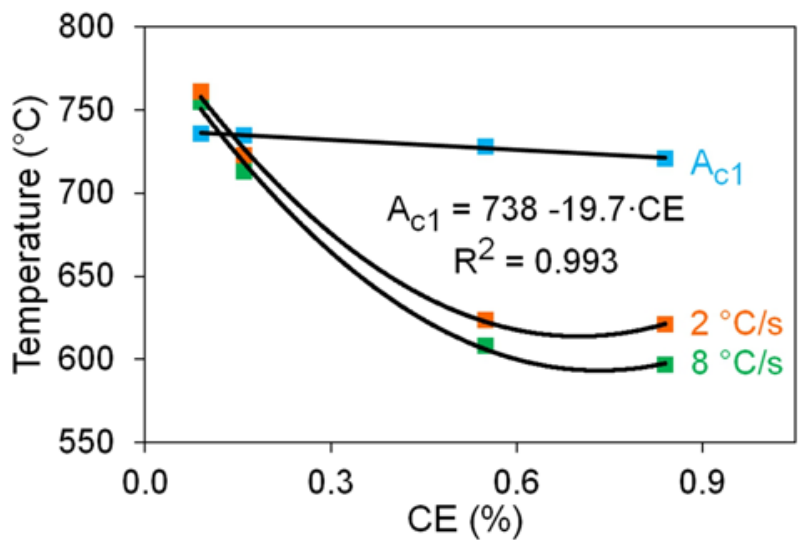

Fig. 8. Temperatures $A_{\mathrm{c} 1}$ and $A_{\mathrm{r} 1}$ (for cooling rates of 2 and $\left.8^{\circ} \mathrm{C} \mathrm{s}^{-1}\right)$ in dependence on $C E$ values.

dependence of $A_{\mathrm{r} 3}=f\left(A_{\mathrm{c} 3}\right)$ has a very similar slope for both cooling rates.

Based on these findings, it was easy to build a linear dependence of the $A_{\mathrm{r} 3}$ variable on two independent variables - the calculated $A_{\mathrm{c} 3}$ temperature and the cooling rate $\mathrm{CR}$ :

$$
A_{\mathrm{r} 3}=1.375 A_{\mathrm{c} 3}-2.3 \mathrm{CR}-339 .
$$

The accuracy of Eq. (4) is demonstrated by the determination coefficient $R^{2}=0.990$, the standard deviation of $11^{\circ} \mathrm{C}$ and the graph in Fig. 7. Analogous regressions using the substitution of the independent variable $A_{\mathrm{c} 3}$ with carbon content or carbon equivalent always resulted in a less precise description of the $A_{\mathrm{r} 3}$ value.

Complications in describing the experimentally determined values of $A_{\mathrm{r} 1}$ have already been signaled by the graph in Fig. 8. While the dependence $A_{\mathrm{c} 1}=$ $f(C E)$ is practically entirely linear, the analogous 
Table 4. Transformation temperatures obtained experimentally and calculated according to Eqs. (4) and (5)

\begin{tabular}{ccccccc}
\hline Steel & $\begin{array}{c}C E \\
(\%)\end{array}$ & $\begin{array}{c}\mathrm{CR} \\
\left({ }^{\circ} \mathrm{C} \mathrm{s}^{-1}\right)\end{array}$ & $\begin{array}{c}\text { Measured } A_{\mathrm{r} 3} \\
\left({ }^{\circ} \mathrm{C}\right)\end{array}$ & $\begin{array}{c}\text { Calculated } A_{\mathrm{r} 3} \\
\left({ }^{\circ} \mathrm{C}\right)\end{array}$ & $\begin{array}{c}\text { Measured } A_{\mathrm{r} 1} \\
\left({ }^{\circ} \mathrm{C}\right)\end{array}$ & $\begin{array}{c}\text { Calculated } A_{\mathrm{r} 1} \\
\left({ }^{\circ} \mathrm{C}\right)\end{array}$ \\
\hline $\mathrm{U}$ & 0.09 & 2 & 879 & 886 & 761 & 768 \\
$\mathrm{~L}$ & 0.16 & 2 & 859 & 849 & 723 & 718 \\
$\mathrm{M}$ & 0.55 & 2 & 728 & 738 & 624 & 633 \\
$\mathrm{H}$ & 0.84 & 2 & 684 & 677 & 621 & 754 \\
$\mathrm{U}$ & 0.09 & 8 & 872 & 872 & 713 & 704 \\
$\mathrm{~L}$ & 0.16 & 8 & 843 & 711 & 608 & 619 \\
$\mathrm{M}$ & 0.55 & 8 & 669 & 663 & 597 & 595 \\
$\mathrm{H}$ & 0.84 & 8 & 711 & & \\
\hline
\end{tabular}

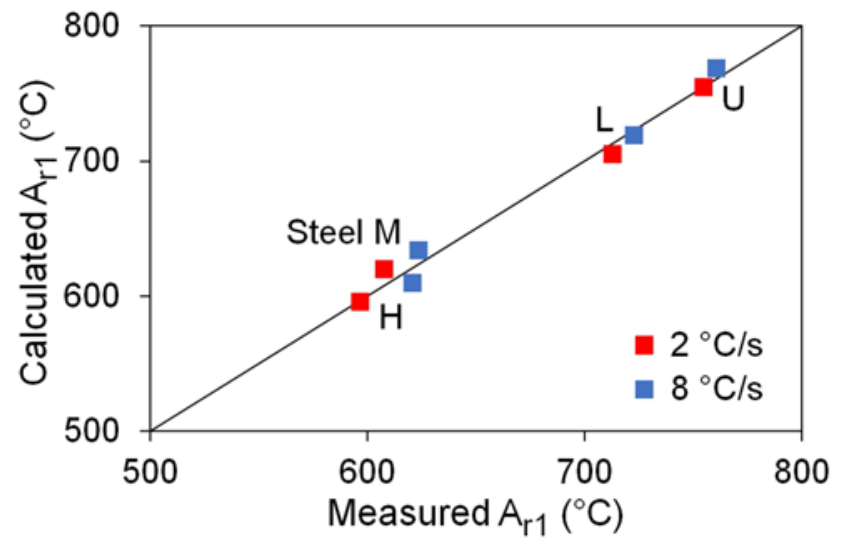

Fig. 9. The relation between measured and calculated $A_{\mathrm{r} 1}$ temperatures (according to Eq. (5)) (distinguishing the values obtained at cooling rates of 2 and $\left.8^{\circ} \mathrm{C} \mathrm{s}^{-1}\right)$.

$A_{\mathrm{r} 1}=f(C E)$ dependences have a distinct polynomial character and are not directly related to the $A_{\mathrm{c} 1}$ values. For the $\mathrm{U}$ steel with the lowest carbon content, even values of $A_{\mathrm{r} 1}>A_{\mathrm{c} 1}$ were calculated, which is contrary to theoretical assumptions.

After testing the different models, the relatively optimal way of mathematical description of $A_{\mathrm{r} 1}$ temperature is the relationship:

$$
A_{\mathrm{r} 1}=202.75 C E^{-0.25}-2.3 \mathrm{CR}+402 .
$$

The accuracy of Eq. (5) is illustrated by the coefficient of determination $R^{2}=0.986$ (slightly lower than for Eq. (4)), the standard error of $11^{\circ} \mathrm{C}$ and the graph in Fig. 9. All predicted values (according to Eqs. (4) and (5)) are listed and compared with the measured transformation temperatures in Table 4.

\section{Discussion of results}

Phenomenological models of Eqs. (4) and (5) describe experimental data with good accuracy (especially for $A_{\mathrm{r} 3}$ temperature - with a maximum relative error of $1.9 \%$ and a standard deviation of $1.1 \%$ ) and show two basic advantages. Above all, it is their simplicity, predestinating them to fast and easy prediction of the transformation temperatures $A_{\mathrm{r} 3}$ and $A_{\mathrm{r} 1}$ of hypoeutectoid carbon steels, more or less only by their chemical composition knowledge. Compared to this, the approaches of some other authors are more complex and sophisticated, but also much more demanding for the calculations. For example, Serajzadeh and Karimi Taheri [19] developed a model to predict the kinetics of austenite decomposition during the continuous cooling of low-carbon steel. Their approach was based on a two-dimensional finite element model and the assumption of a second order transformation in austenite. The model considers the effects of phase transformations latent heat, initial austenite grain size, deformation hardening of austenite, etc. $\mathrm{Su}, \mathrm{Ma}$ and Han [20] simulated the decomposition of austenite into ferrite and pearlite during the continuous cooling of the hypoeutectoid steel with the cellular automaton method.

Another advantage of the developed Eqs. (4) and (5) is that they include the effect of relatively high cooling rates $2-8^{\circ} \mathrm{Cs}^{-1}$, which are closely related to real operating conditions. Most experiments by other authors were performed at cooling rates of a lower order (see, for example, $5^{\circ} \mathrm{C} \min ^{-1}[21], 5-20^{\circ} \mathrm{C} \mathrm{min}^{-1}$ $[18,22]$, or $\left.20^{\circ} \mathrm{C} \mathrm{min}^{-1}[23]\right)$. This, on the other hand, allowed a much more stable drawing of the dilatometric curves and their more reliable analysis, leading to a more exact determination of the individual phase transformation temperatures. For example, it was possible to determine $A_{\mathrm{r} 3}, A_{\mathrm{r} 1}$, and also $A_{\mathrm{rp}}$ temperatures (at which austenite decomposition begins, the eutectoid reaction starts and the eutectoid reaction finishes during cooling, respectively). Such precise definition of $A_{\text {r1 }}$ and $A_{\text {rp }}$ temperatures was not possible in the case of dilatometry measurements at high cooling rates.

However, the certain disadvantage of both developed phenomenological models is also related to the experimentally limited range of cooling rates. The simple linear dependence of the transformation temperatures on the cooling rate cannot enable the ex- 
Table 5. Comparison of literary data and calculated transformation temperatures for cooling rate of $0.33^{\circ} \mathrm{Cs}^{-1}$

\begin{tabular}{|c|c|c|c|c|c|c|}
\hline $\begin{array}{l}\mathrm{C} \\
(\%)\end{array}$ & $\begin{array}{c}C E(\%) \\
(\%)\end{array}$ & $A_{\mathrm{r} 3}-\underset{\left({ }^{\circ} \mathrm{C}\right)}{\text { measured }}$ & $\begin{array}{c}A_{\mathrm{r} 3}-\underset{\left({ }^{\circ} \mathrm{C}\right)}{\text { Eq. }}(4)\left({ }^{\circ} \mathrm{C}\right) \\
\end{array}$ & $A_{\mathrm{r} 1}-\underset{\left({ }^{\circ} \mathrm{C}\right)}{\operatorname{measured}}\left({ }^{\circ} \mathrm{C}\right)$ & $\begin{array}{c}A_{\mathrm{r} 1}-\underset{\left({ }^{\circ} \mathrm{C}\right)}{\text { Eq. }}(5)\left({ }^{\circ} \mathrm{C}\right) \\
\end{array}$ & Ref. \\
\hline 0.072 & 0.14 & 849 & 857 & $\mathrm{~N} / \mathrm{A}$ & 733 & [23] \\
\hline 0.103 & 0.19 & 825 & 838 & $\mathrm{~N} / \mathrm{A}$ & 708 & [23] \\
\hline 0.12 & 0.26 & 845 & 840 & 674 & 685 & [18] \\
\hline 0.214 & 0.31 & 767 & 800 & 666 & 672 & [23] \\
\hline 0.364 & 0.53 & 742 & 754 & 665 & 639 & [23] \\
\hline 0.468 & 0.65 & 716 & 725 & 642 & 627 & [23] \\
\hline
\end{tabular}

Table 6. Comparison of $A_{\mathrm{r} 3}$ values obtained by measurement and calculations according to different equations

\begin{tabular}{ccccccc}
\hline & & \multicolumn{5}{c}{$A_{\mathrm{r} 3}\left({ }^{\circ} \mathrm{C}\right)$} \\
\cline { 4 - 6 } Steel & $\begin{array}{c}\mathrm{C} \\
(\%)\end{array}$ & $\begin{array}{c}\mathrm{CR} \\
\left({ }^{\circ} \mathrm{C} \mathrm{s}^{-1}\right)\end{array}$ & Measured & Eq. $(4)$ & Eq. $(6)[16]$ & Eq. $(7)[32]$ \\
\hline $\mathrm{U}$ & 0.029 & 2 & 879 & 886 & 849 & 848 \\
$\mathrm{U}$ & 0.029 & 8 & 872 & 872 & 849 & 848 \\
$\mathrm{~L}$ & 0.084 & 2 & 859 & 849 & 829 & 813 \\
$\mathrm{~L}$ & 0.084 & 8 & 843 & 835 & 829 & 744 \\
$\mathrm{M}$ & 0.42 & 2 & 728 & 738 & 726 & 744 \\
$\mathrm{M}$ & 0.42 & 8 & 711 & 725 & 727 & 693 \\
$\mathrm{H}$ & 0.73 & 2 & 684 & 677 & 646 & 693 \\
$\mathrm{H}$ & 0.73 & 8 & 669 & 663 & 646 & \\
\hline
\end{tabular}

trapolation of Eqs. (4) and (5) for significantly lower or higher cooling rates. Long et al. [22] developed an empirical model to describe the relationships between the critical temperatures of the austenite transformation $\left(A_{\mathrm{r}}\right)$ and the cooling rate $\mathrm{CR}$, written as $A_{\mathrm{r}}=a-\exp (b+c / \mathrm{CR})$, where $a, b$ and $c$ are material constants. The combination of reciprocal and exponential function in $A_{\mathrm{r}}=f(\mathrm{CR})$ dependence is more physically justified than a linear dependence used in Eqs. (4) and (5).

Additional restriction for Eqs. (4) and (5) is that they do not reflect the effect of the initial austenitic grain size or the previous deformation. Many experimental works have shown that these effects can be very significant. It was not only a favourite dilatometry test (see e.g. [9, 24-27]), but also laboratory rolling tests [4], or experiments using intermittent compression [28] or torsion deformation [25, 29, 30]. Non-isothermal tests can then even determine an important non-recrystallization temperature simultaneously with phase transformation temperatures in the course of cooling [29].

It should be noted that dilatometric tests are based on the cooling of the sample at a constant rate. Cooling parameters in operating conditions are much more complex. Even with a free-air cooling, the CR variable gradually changes with decreasing temperature and mainly due to exothermic phase transformations. This can also be simply validated by continuous mea- suring the surface temperature of the cooling sample - see e.g. [31].

From literary sources $[18,23]$, the obtained temperatures $A_{\mathrm{r} 3}$ and $A_{\mathrm{r} 1}$ data were compared with calculations according to the developed models. The data in Table 5 relate to a single cooling rate of $20^{\circ} \mathrm{C} \mathrm{min}-1$ (i.e., $0.33^{\circ} \mathrm{C} \mathrm{s}^{-1}$ ). Measured $A_{\mathrm{r}}$ values were listed explicitly in the paper or had to be subtracted from the curves after digitization of the published graphs in the Origin software. The consistency of predicted and experimental values is fairly reasonable when we consider that Eqs. (4) and (5) have been developed for higher cooling rates only. Exceptionally different values are for $A_{\mathrm{r} 3}$ temperatures of steel with $0.214 \% \mathrm{C}$. For steels with $0.364 \%$ and $0.468 \% \mathrm{C}$, the situation was additionally complicated by high sulfur content (above $0.2 \%$ ). Therefore, derived models seem to be quite convenient even for cooling rates $C E<1^{\circ} \mathrm{Cs}^{-1}$.

There are formulas from various authors designed to predict the $A_{\mathrm{r} 3}$ temperature of unalloyed steels carbon or microalloyed ones. For example, Vanderschueren et al. [16] used a simple dependence on the content of four elements, without considering other independent variables (such as cooling rate):

$$
A_{\mathrm{r} 3}=865-280 \mathrm{C}-60 \mathrm{Mn}+60 \mathrm{Si}+600 \mathrm{P} .
$$

Mintz, Banerjee, and Banks [32] attempted to include the effect of chemical composition, the austenitic 


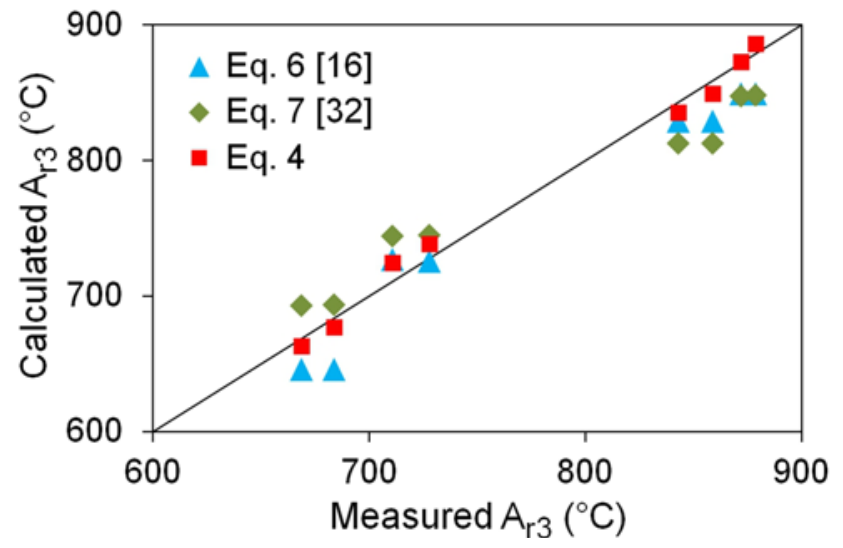

Fig. 10. The accuracy of calculation of $A_{\mathrm{r} 3}$ temperatures according to different equations.

grain size in as-cast steels as well as the cooling rate, but at last, they recommended the simplified relationship:

$$
\begin{gathered}
A_{\mathrm{r} 3}=862-182 \mathrm{C}-76.1 \mathrm{Mn}+1121 \mathrm{~S}+1804 \mathrm{Nb}+\cdots \\
+1168 \mathrm{Ti}-2852 \mathrm{~N}-0.084 \mathrm{CR},
\end{gathered}
$$

valid for $0.04-0.75 \% \mathrm{C}, 0.31-2.52 \% \mathrm{Mn}, 0.01-1.22 \%$ Si, $0.001-0.032 \% \mathrm{~S}, 0-0.042 \% \mathrm{Nb}$, grain size 100 $1000 \mu \mathrm{m}$ and cooling rate $0.17-3.33^{\circ} \mathrm{C} \mathrm{s}^{-1}$.

In Table 6 , temperatures $A_{\mathrm{r} 3}$ for the tested steels $\mathrm{U}, \mathrm{L}, \mathrm{M}$, and $\mathrm{H}$ were determined experimentally and by calculation according to different equations. The new model described by Eq. (4) most accurately describes the experimental data - see also Fig. 10. Equations of other authors not at all or only insufficiently reflect the effect of the cooling rate; this way calculated temperatures $A_{\mathrm{r} 3}$ show significant deviations from the values measured especially at the lowest and highest applied carbon content.

\section{Conclusions}

- For unalloyed hypoeutectoid steels with a carbon content of 0.029 to $0.73 \%$, based on dilatometric tests the $A_{\mathrm{r} 3}$ and $A_{\mathrm{r} 1}$ transformation temperatures have been described with good accuracy at a relatively high cooling rate $2-8^{\circ} \mathrm{C} \mathrm{s}^{-1}$.

- The given cooling rate interval corresponds e.g. to conditions in controlled cooling of a rolled wire rod and is therefore highly appreciated from the practical point of view.

- The developed phenomenological models (Eqs. (4) and (5)) allow a simple prediction of the transformation temperatures, depending on the cooling rate and chemical composition, which is represented by the carbon equivalent and by the $A_{\mathrm{c} 3}$ temperature in case of $A_{\mathrm{r} 1}$ and $A_{\mathrm{r} 3}$ values, respectively.
- The derived equations can also be used for orderly lower cooling rates when austenite transforms exclusively on ferrite and pearlite. Extrapolation for significantly higher cooling rates could be more complicated by the formation of other phase components.

- The new Eq. (4) for temperature $A_{\mathrm{r} 3}$ is significantly more precise in describing the relevant experimental data than the empirical models of other authors $[16,32]$. The reason is probably its relation to the non-linear dependence of the temperature $A_{\mathrm{c} 3}=$ $f\left(\mathrm{C}^{1 / 2}\right)$.

- A by-product of the performed regression analyses was the finding of a very close relationship between the carbon equivalent according to International Institute of Welding and the $A_{\mathrm{c} 3}$ temperature calculated according to [14].

\section{Acknowledgements}

The implemented experimental work was supported by the Ministry of Education, Youth and Sports of the Czech Republic through three grant projects: LO1203, CZ.1.05/2.1.00/19.0387, and SP2018/105.

\section{References}

[1] Hall, E. O.: P. Phys. Soc. Lond., 64, 1951, p. 747. doi:10.1088/0370-1301/64/9/303

[2] Petch, N. J.: J. Iron Steel I., 174, 1953, p. 25.

[3] Niels, H.: Scripta Mater., 51, 2004, p. 801. doi:10.1016/j.scriptamat.2004.06.002

[4] Schindler, I., Rusz, S., Opěla, P., Rusz, J., Solowski, Z., Čmiel, K. M.: Kovove Mater., 55, 2017, p. 229. http://kovmat.sav.sk/issue.php?rr $=55 \& c c=4$

[5] Kawulok, P., Kawulok, R., Schindler, I., Rusz, S., Kliber, J., Unucka, P., Čmiel, K. M.: Metalurgija, 53, 2014, p. 299. https://hrcak.srce.hr/119535

[6] Liu, S. K., Yang, L., Zhu, D. G., Zhang, J.: Metall. Mater. Trans. A, 25, 1994, p. 1991. doi:10.1007/BF02649047

[7] Khlestov, V. M., Konopleva, E. V., McQueen, H. J.: Mater. Sci. Tech., 18, 2002, p. 54. doi:10.1179/026708301125000212

[8] Kawulok, R., Schindler, I., Kawulok, P., Rusz, S., Opěla, P., Solowski, Z., Čmiel, K. M.: Metalurgija, 54, 2015, p. 473. https://hrcak.srce.hr/131600

[9] Nürnberger, F., Grydin, O., Schaper, M., Bach, F. W., Koczurkiewicz, B., Milenin, A.: Steel Res. Int., 81, 2010, p. 224. doi: $10.1002 / \operatorname{srin} .200900132$

[10] Kruglova, A. A., Orlov, V. V., Khlusova, E. I.: Met. Sci. Heat Treat., 49, 2007, p. 556. doi:10.1007/s11041-007-0102-x

[11] Lee, S. J., Lee, Y. K.: Mater. Design, 29, 2008, p. 1840. doi:10.1016/j.matdes.2008.03.009

[12] Kawulok, R., Skandera, D., Kawulok, P., Schindler, I., Rusz, S., Solowski, Z.: In: Proceedings of Conference Metal 2017. Ostrava, Tanger Ltd. 2017, p. 383.

[13] Dearden, J., O’Neill, H.: Trans. I. Weld., 3, 1940, p. 203. 
[14] Trzaska, J., Dobrzański, L. A.: J. Mater. Process. Tech., 192, 2007, p. 504. doi:10.1016/j.jmatprotec.2007.04.099

[15] Gleeble ${ }^{(\mathbb{k}}$ Systems Catalog (DSI-14-V1). New York, Dynamic Systems Inc. 2014.

[16] Vanderschueren, D., Kestens, L., Van Houtte, P., Aernoudt, E., Dilewijns, J., Meers, U.: Mater. Sci. Tech., 6, 1990, p. 1247. doi:10.1179/mst.1990.6.12.1247

[17] García de Andrés, C., Caballero, F. G., Capdevila, C., Álvarez, L. F.: Mater. Charact., 48, 2002, p. 101. doi:10.1016/S1044-5803(02)00259-0

[18] Zhang, J., Chen, D. F., Zhang, Ch. Q., Hwang, W. S., Han, M. R.: J. Mater. Res., 30, 2015, p. 2081. doi:10.1557/jmr.2015.173

[19] Serajzadeh, S., Karimi Taheri, A.: Mater. Design, 25, 2004, p. 673. doi:10.1016/j.matdes.2004.03.006

[20] Su, B., Ma, Q., Han, Z.: Steel Res. Int., 88, 2017, Article Number UNSP 1600490. doi:10.1002/srin.201600490

[21] Laptev, A., Baufeld, B., Swarnakar, A. K., Zakharchuk, S., Van der Biest, O.: J. Mater. Eng. Perform., 21, 2012, p. 271. doi:10.1007/s11665-011-9921-4

[22] Long, M., Dong, Z., Chen, D., Zhang, X., Zhang, L.: Iron. Steelmaking, 42, 2015, p. 282. doi:10.1179/1743281214Y.0000000227

[23] Kop, T. A., Sietsma, J., Van der Zwaag, S.: J. Mater. Sci., 36, 2001, p. 519. doi:10.1023/A:1004805402404

[24] Farrar, R. A., Zhang, Z., Bannister, S. R., Barritte, G. S.: J. Mater. Sci., 28, 1993, p. 1385. doi:10.1007/BF01191982
[25] Petrov, R., Kestens, L., Houbaert, Y.: Mater. Charact., 53, 2004, p. 51. doi:10.1016/j.matchar.2004.07.005

[26] Aranda, M. M., Kim, B., Rementeria, R., Capdevila, C., García de Andrés, C.: Metall. Mater. Trans. A, 45, 2014, p. 1778. doi:10.1007/s11661-013-1996-0

[27] Kawulok, R., Schindler, I., Kawulok, P., Rusz, S., Opěla, P., Kliber, J., Solowski, Z., Cmiel, K. M. Podolínský, P., Mališ, M., Vašek, Z., Vančura, F.: Metalurgija, 55, 2016, p. 357. http://hrcak.srce.hr/file/226318

[28] Nowotnik, A., Sieniawski, J., Wierzbińska, M.: Achieve. Mater. Manuf. Eng., 20, 2007, p. 267. http://iamme.acmsse.h2.pl/papers_vol20/1354S.pdf

[29] Vega, M. I., Medina, S. F., Chapa, M., Quispe, A.: ISIJ Int., 39, 1999, p. 1304. doi:10.2355/isijinternational.39.1304

[30] Sun, L., Muszka, K., Wynne, B. P., Palmiere, E. J.: Metall. Mater. Trans. A, 45, 2014, p. 3619. doi:10.1007/s11661-014-2283-4

[31] Rusz, S., Schindler, I., Kawulok, P., Kawulok, R., Opěla, P., Kliber, J., Solowski, Z.: Metalurgija, 55, 2016, p. 655. http://hrcak.srce.hr/157390

[32] Mintz, B., Banerjee, J. R., Banks, K. M.: Iron. Steelmaking, 38, 2011, p. 197. doi:10.1179/030192310X12827375731429 